VOL 2 (2018) NO 4 - 2

e-ISSN : 2549-9904

ISSN : 2549-9610

INTERNATIONAL JOURNAL ON INFORMATICS VISUALIZATION

\title{
Implementing FAST Method on the Development of Object-Oriented Cooperative Information Systems
}

\author{
Meri Azmi", Yance Sonatha\#, Ervan Asri", Rasyidah", Dwi Sudarno Putra* \\ \# Information Technology Department, Politeknik Negeri Padang, Indonesia \\ *Automotive Department, Faculty of Engineering,. Universitas Negeri Padang, Indonesia \\ E-mail:meriazmi@pnp.ac.id
}

\begin{abstract}
Cooperative is one form of businesses that is widely known as people concern and has a legal entity. In helping its members, the cooperative embraces familial value principle and mutual cooperation for the common social welfare. In carrying out its duties and functions, the cooperative requires an accurate and accountable recording. However, currently there are still many cooperatives performing their recording manually. Therefore, an information systems is needed in assisting the cooperative management in term of this recording. This research developed an object-oriented cooperative information systems using FAST method. Its purpose is to develop a cooperative information systems that can facilitate its administrators in order to record the data through information systems-based, so the inaccuracy in recording, and loss of important data and archives can be avoided. Its result is a system that has been implemented into a cooperative. Hence, the information systems is developed using Java Programming language and MySQL database. From the system testing results shows that this information systems is capable in processing the accounting data associated with savings and loan transactions automatically, and produce information in the form of managerial and financial reports.
\end{abstract}

Keywords - Information Systems, Object-Oriented Systems, FAST.

\section{INTRODUCTION}

A cooperative is a business organization where its members are individuals or cooperatives legal entities in which its operation is based on cooperative principles, and treated as people economic movement based on familial principles. It is a cooperative according to Law of Republic of Indonesia Number 25 Year 1992 [1]. It can be taken into a note that cooperative is particularly aimed to raise social wealth, to have economic and social elements seen from the familial principle upheld by the cooperative [2].

There are many types of cooperative, and one of them is Saving and Loan cooperative. This type of cooperative has two functions, first is saving where the society can save and deposit their money, and the second one is loan where the society can make mortgage and other loans with the lowest interest in order to establish and develop their planned business. Therefore, cooperative plays a significant role in society's economic growth in Indonesia.

Cooperative always adapt with the the development of relevant knowledge, including the use of information technology in organizing and managing a cooperative. However, up to recent time, its management with information system-based has not yet optimal.
From the conducted library research, there has been a few developments of this cooperative information systems earlier, and given a good impact to the cooperative itself as it can assist the cooperative in running its job and function. One among many previous researches was the study of the information systems development on Civil Servant Cooperative (CSC) Kapur Warna in Padang [3]. This study concentrates on the development of cooperative information systems using waterfall method. Another related research was the development of information systems on Islamic (sharia) financial services [4]. Its result showed that the system has been developed and implemented on the research object, and it ran well. Hence, the method applied in the mentioned above research applied the waterfall method as well. The next research was the one about the development of cooperative information systems using a web-based RAD (Rapid Application Development) method [5].

Moreover, this present research aims to develop an information systems on saving and loan cooperative using object-oriented system with FAST (Framework for the Application on System Thinking) method. Whereas, its object was the cooperative in Perumdak Housing Complex which has been established since 2005. During its Annual General Meeting (RAT) in 2017, this cooperative had 101 members [6]. One of its business is saving and loan. To run 
its job and fuction, this cooperative has carried out a recording with information systems-based, by applying microsoft excel. However, this recording has been inefficient and ineffective as the stored data is unstructured, and takes time for data searching process. Despite this problem, the construction of an information systems in order to automatically manage and process the data is required.

\section{LITERATURE REVIEW}

\section{A. Information Systems}

Information systems has three definitions as listed below [7] :

1. Information systems is a man-made, that has an integrated set of components within an organization in order to disseminate information.

2. Information systems is a group of organization procedures where at the time it is implemented, it is going to provide feed back in the form of useful information for decision making, and or for managing an organization.

3. Information systems is a system within an organization setting that combines the transactional management needs, supports the operational, is managerial, and is a strategic activity of an organization in providing reports which can be used by many parties.

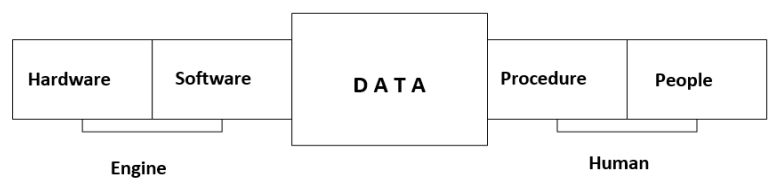

Fig. 1. Five components of information systems [7]

Information Systems Components:

1. Hardware and software which can be used to run an information systems (engine).

2. People and procedures are human who will run the information systems.

3. Data is functioned as the connector between people and engine to make the data processing occured.

\section{B. Unified Modelling Language (UML)}

Usually UML is applied to construct a system using object-oriented programming. It comes from the combination of numerous object-oriented programming language at the end of 1980s. UML is a collection of multiple pieces of equipment which are used to do abstraction toward the softwate or object-oriented system. It gives amenity to sustainable application development [8]. There are several diagrams which are generally used in UML, they are:

1. Class Diagram consists of class, interface, association, and collaboration. It describes the objects within the systems.

2. Use Case Diagram describes a set of use case, actor, and their connection. It is the collaboration between systems functionality with internal/ external actor of the systems.

3. Sequence Diagram describes the interaction which explains how the message conveyed from one object to another.
4. Activity Diagram describes the flow of system control. It is used in order to observe how the systems works when it is executed.

\section{Framework for the Application on System Thinking} (FAST)

Systems development methodology is technique and framework used in designing a system. This methodology is varied, one of them is the commonly used methodology systems which is Framework for the Application of Systems Technique (FAST) [9].

FAST Methodology consists of stages as listed below [9]:

1. Preliminary Investigation. At this stage, there are several actions being carried out; collect the information in the form of problem, determine the users opportunities and purposes, and also to set the scope of the project which will be done. The purpose of this stage is to determine the problems in the object being observed. Here, the chances to improve the organization work performance, and new established needs which is put into the management and other relevant parties are obtained.

2. Problem Analysis. At this stage, the observation to the existing systems is performed such as studying and analyzing, identifying various problems that occured, and finding solution for those problems.

3. Requirements Analysis. At this stage, the identification on the needs is carried out. Its purpose is to identify the existing data, the process within the data processing, and the interface required by the users of the systems which will be developed.

4. Decision Analysis. At this stage, the analysis is performed on the hardware and software which will be chosen and used in order to implement the systems as the answers to the problem, and as the solutions which have been identified in the previous stages.

5. Design. The purpose of this stage is transforming the users's needs from the earlier stages into the model systems whicl will be constructed later.

6. Construction and Testing. At this stage the development of information systems is conducted, in the form of database establishment, application program, and interface which is in accordance with the business needs and design specification as required by early stages. Furthermore, there will be testing stage on the developed systems. After going through comprehensive testing on all the systems, then the systems is ready to be implemented.

7. Implementation. At this stage, the implementation onto the developed system is carried out including the training for the systems users.

\section{Saving and Loan Cooperative}

The presence of this saving and loan cooperative can improve the economic of those who become the member of this cooperative. It is because this cooperative is established in order to give opportunities to its members to receive loan with the lowest interest. This cooperative gives positive impacts onto its members as it saves them from moneylender 
Saving and Loan Cooperative is a cooperative that provides the service of accepting the fund from its members, and then this fund is going to be lent to other members who are in need [10].

\section{METHOD}

The developed information systems in this research applied FAST methodology consisting of eight stages which were conducted sequentially. Soon after the implementation stage was completed, the maintenance stage then was performed. It was expected that these two stages would provide the feedback onto the analysis systems which had been designed. Therefore, the development stage could be carried out continously in order to obtain well-designed systems [11].

\section{A. Research Location}

The research location was in Perumdak Housing Complex which was located in Padang City, West Sumatera. The activity was the development of cooperative information systems which was done in the laboratorium of Information Technology Department, Politeknik Negeri Padang.

\section{B. Tools and Materials}

Tools and materials used were the relevant hardware and software that supported the development of this information systems.

\section{Data Types}

The data used were:

1. Primary Data

Taken from the cooperative members's data, saving and loan data, report of cooperative annual general meeting.

2. Secondary Data

Taken from the library, relevant books and journals to this research.

\section{Research Procedures}

This research was aimed to develop a cooperative information systems. The conducted procedures followed the stages in FAST Methodology.

1. Preliminary Investigation. This stage was started by collecting the relevant information with the Perumdak Housing Complex Cooperative. Then, continued to formulate the problems and the scopes, identified the opportunities of the problems solution, and carried out the assessment on the existing systems feasibilty which had been running.

2. Problem Analysis. The conducted activity at this stage was identifying and evaluating the problems, opportunities, obstacles that had been occured, and identified the solution of the problems and the needs toward the anticipated systems by Perumdak Housing Complex Cooperative's committee and its members.

3. Requirement Analysis. Collecting and analyzing the data was carried out at this stage, particularly on the data which was collaborated with the users who would use the systems (committee and employee). The needs of each user was then identified to be used as the secondary data in the development of cooperative information systems.
4. Decision Analysis. At this stage, the selection was performed on the development model, and also on hardware and software that would be used to develop the cooperative information systems that would be constructed.

5. Design. At this stage, the transformation was done from the users needs of the cooperative information systems onto the model which would be constructed.

6. Construction and Testing. The conducted activity at this stage was developing the cooperative information systems. The development was in the form of database establishment, application program, and appropriate interface with the users needs which had been identified in the previous stages. Afterward, the testing on the information systems was performed by examining whether there was an error occured or whether there was a change toward the systems in accordance with the users demand.

7. Implementation. At this stage, the information systems on the Cooperative of Perumdak Housing Complex was being installed. As an additional, the training for the users; the cooperative committee and the employee regarding to the use of the constructed information systems was performed as well.

\section{IV.RESULTS AND DISCUSSION}

\section{A. Preliminary Investigation}

1. Problems

To gather the information in the form of problems faced by this housing complex cooperative, the direct observation onto this ongoing system was conducted. Besides that, the interview session to the committee and the employee as people who ran this present systems was also taken in order to enrich the data received. Indicated from the observation and the interview results, some problems faced by this cooperative for all these years could be drawn up, listed as below:

- Storing the data that was still conducted manually using several manual applications like Ms. Excel, Ms. Word, up to HVS paper, so the data was frequently lost, and took quite a time to process it.

- Writing the report that was still performed in simple and manual way, where it sometimes made the data was written inaccurately, and many errors made during the writing process.

2. Opportunities

During the direct observation and interview session, it could be seen that the committee and the employee of this cooperative were so enthusiastic doing some changes into the cooperative information systems in order to make the data input, saving and loan estimation process, and report writing could run well and produce an accurate data.

3. Scopes

The anticipated result was to establish a cooperative information systems which could be used by its committee and employee.

4. Feasibility Study

Seen from the result of feasibility study, there were several issues that could support the implementation of this systems, they were: 
- The availability of the technology like personal computer where the cooperative committee (operator) was proficient in operating it.

- The cooperative employee had the ability in operating the personal computer not only the hardware but also the software.

\section{B. Problem Analysis}

At this stage, there were several weaknesses determined on the ongoing systems. Taken into note, there were several suggestions or solutions given to overcome those weaknesses. For further details, the identification and the solutions of the problems can be seen in Table 1 .

TABLE I.

IDENTIFICATION OF PROBLEM SOLUTION

\begin{tabular}{|l|l|l|l|}
\hline $\begin{array}{l}\text { The ongoing } \\
\text { systems } \\
\text { problem }\end{array}$ & Data loss & $\begin{array}{l}\text { Data processing } \\
\text { which takes } \\
\text { quite a time }\end{array}$ & $\begin{array}{l}\text { Inaccurate and } \\
\text { faulty report }\end{array}$ \\
\hline $\begin{array}{l}\text { Problems } \\
\text { solution }\end{array}$ & $\begin{array}{l}\text { Make use of the } \\
\text { cooperative } \\
\text { information } \\
\text { systems using } \\
\text { the database } \\
\text { management } \\
\text { systems }\end{array}$ & $\begin{array}{l}\text { Database } \\
\text { management } \\
\text { systems on the } \\
\text { cooperative } \\
\text { information } \\
\text { systems provides } \\
\text { simplicity in } \\
\text { accessing the } \\
\text { data punctually. }\end{array}$ & $\begin{array}{l}\text { Cooperative } \\
\text { information } \\
\text { systems can } \\
\text { produce and report, } \\
\text { punctual reporinimize } \\
\text { and ming } \\
\text { the errors made }\end{array}$ \\
\hline
\end{tabular}

Obviously in accordance with problems and their solutions mentioned above suggested a settlement by harnessing the cooperative information systems. The established information systems could assist in overcoming the obstacles faced formerly, which were:

1. This information systems accommodated the cooperative employee to process the data input and transaction.

2. Data storage in the form of database.

3. This information systems simplified the adequate report writing.

\section{Requirements Analysis}

The goal of this analysis was in order to acknowledge the process and information or any reports which were requisite by the users. It could be ascertained from the direct observation and interview process with the cooperative committee and employee. Then, the necessity of each users was identified to become secondary data in the construction of cooperative information systems.

\section{Decision Analysis}

At this stage, the selection on the model of cooperative information systems, and hardware and software to be used to develop the aforementioned systems was carried out. The result is shown in Table 2.

1. Information Systems Development Model. The development model used the object-oriented systems development that could facilatate the systems developer to design easily.

2. Hardware Selection. The required hardware specification was a computer with minimum I3 processor speed, and 500 GB hardisk storage.
3. Software selection. The chosen software for this systems development was desktop-based Java programming language, and MySQL for the DBMS software.

TABLE II.

Decision Analysis On The Decision Result Of CoOperative INFORMATION SYSTEMS DEVELOPMENT

\begin{tabular}{|l|l|l|}
\hline No & $\begin{array}{l}\text { Analysis of the decision } \\
\text { made }\end{array}$ & Options \\
\hline 1 & $\begin{array}{l}\text { Information Systems } \\
\text { Development Model }\end{array}$ & $\begin{array}{l}\text { Object-oriented } \\
\text { development model in the } \\
\text { form of UML }\end{array}$ \\
\hline 2 & Hardware & Computer hardware \\
\hline 3 & Software & $\begin{array}{l}\text { Desktop-based Java } \\
\text { Programming language } \\
\text { and DBMS MySQL }\end{array}$ \\
\hline
\end{tabular}

\section{E. Design}

The systems design was the allocation of how the form of the new systems would be established. The goal of this systems design was in order to objectify the needs and the desire of the information systems users, and to give describtion and design that would be taken in the program construction. There were several designs implemented in the designing process of the Cooperative Information Systems, i.e Use Case Diagram, Activity Diagram, Class Diagram and Sequence Diagram.

\section{Use Case Diagram Design}

Use Case Diagram depicted how the actors (users) interacting with the information systems [8]. Represented in Fig 2, there were three actors who could access the systems, they were the cooperative member, Admin (the cooperative employee), and the leader of the cooperative. For each actor definition is shown in Table 3. Furthermore, Table 4 highlights the defining of use case in the cooperative information systems. It is seen the process that could be performed on this mentioned systems.

\section{Class Diagram Design}

Class diagram describes various objects in the systems, and the static connection existed in each class. There is also property and operation on this diagram with the present of its boundary [8]. Seen from Fig 3 is the class diagram of cooperative information systems consisting of nine classes.

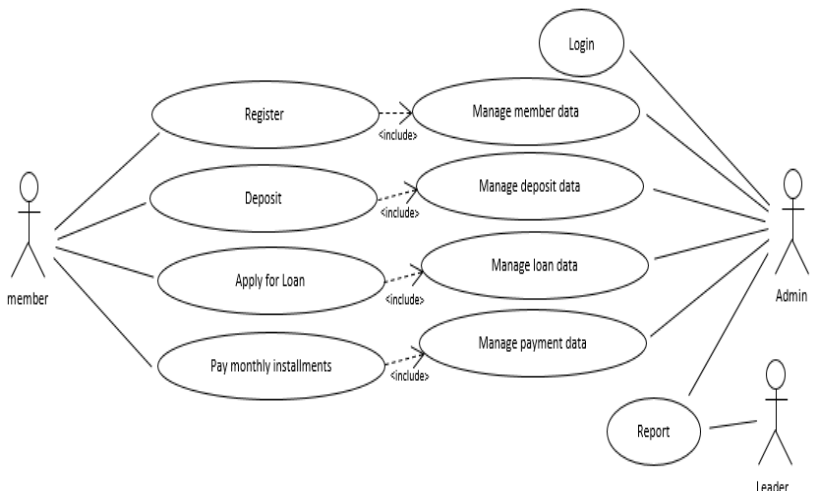

Fig 2. Use Case Diagram of Cooperative Information Systems 
TABLE III.

TABLE OF ACTOR DEFINITION

\begin{tabular}{|l|l|l|}
\hline No & Actor & Description \\
\hline 1 & Member & $\begin{array}{l}\text { The member has the access right to register, store, } \\
\text { borrow, and to do monthly installments }\end{array}$ \\
\hline 2 & Admin & $\begin{array}{l}\text { Admin has the access right to manage all data like } \\
\text { the member data, savings, loans, installments, and } \\
\text { reports. }\end{array}$ \\
\hline 3 & Leader & The leader has the right to read the report. \\
\hline
\end{tabular}

TABLE IV.

TABLe Of USE CASE Definition

\begin{tabular}{|c|c|c|}
\hline No & Use Case & Description \\
\hline 1 & Registering & $\begin{array}{l}\text { The process that should be taken by } \\
\text { a prospective member in registering } \\
\text { themselves as the cooperative } \\
\text { member. }\end{array}$ \\
\hline 2 & Saving & $\begin{array}{l}\text { The process that should be taken by } \\
\text { a member in saving their money. }\end{array}$ \\
\hline 3 & Proposing a loan & $\begin{array}{l}\text { The process that should be taken by } \\
\text { a member in proposing a loan. }\end{array}$ \\
\hline 4 & $\begin{array}{l}\text { Doing monthly } \\
\text { installments }\end{array}$ & $\begin{array}{l}\text { The process that should be carried } \\
\text { out monthly for the loan made by a } \\
\text { member. }\end{array}$ \\
\hline 5 & Login & $\begin{array}{l}\text { The process of checking the } \\
\text { appropriate access right of data } \\
\text { management on Cooperative } \\
\text { Information Systems. }\end{array}$ \\
\hline 6 & $\begin{array}{l}\text { Managing the } \\
\text { members' data }\end{array}$ & $\begin{array}{l}\text { The process which was conducted } \\
\text { by the admin on the prospective } \\
\text { members's registration. }\end{array}$ \\
\hline 7 & $\begin{array}{l}\text { Managing the } \\
\text { savings's data }\end{array}$ & $\begin{array}{l}\text { The process which was conducted } \\
\text { by the admin on the savings made } \\
\text { by the members. }\end{array}$ \\
\hline 8 & $\begin{array}{l}\text { Managing the } \\
\text { loans's data }\end{array}$ & $\begin{array}{l}\text { The process which was conducted } \\
\text { by the admin on the loan given to } \\
\text { the members. }\end{array}$ \\
\hline 9 & $\begin{array}{l}\text { Managing the } \\
\text { installments data }\end{array}$ & $\begin{array}{l}\text { The process which was conducted } \\
\text { by the admin on the installments } \\
\text { made by the members. }\end{array}$ \\
\hline 10 & Report & $\begin{array}{l}\text { The process which was conducted } \\
\text { by the admin displaying the } \\
\text { required data addressed to the } \\
\text { leader. }\end{array}$ \\
\hline
\end{tabular}

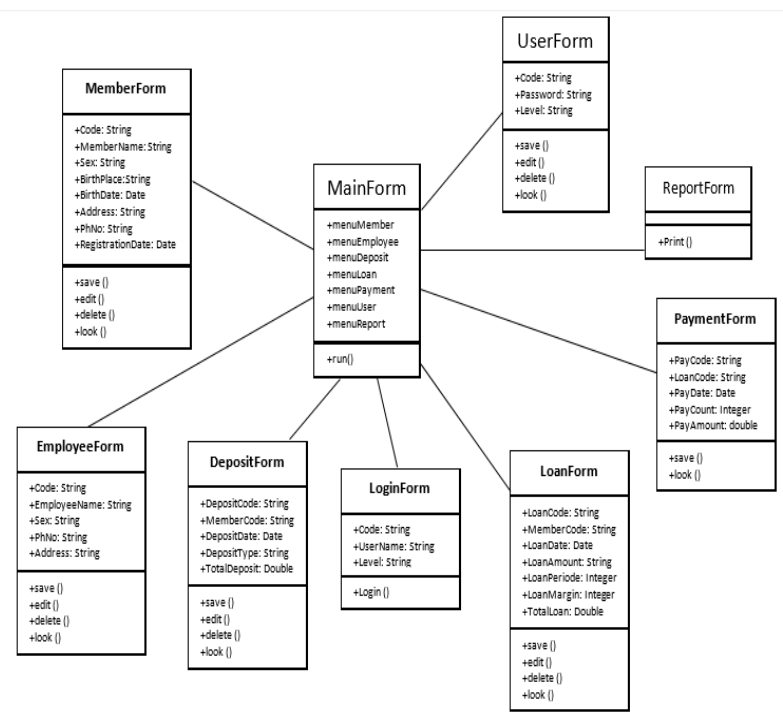

Fig 3. Class Diagram of Cooperative Information Systems

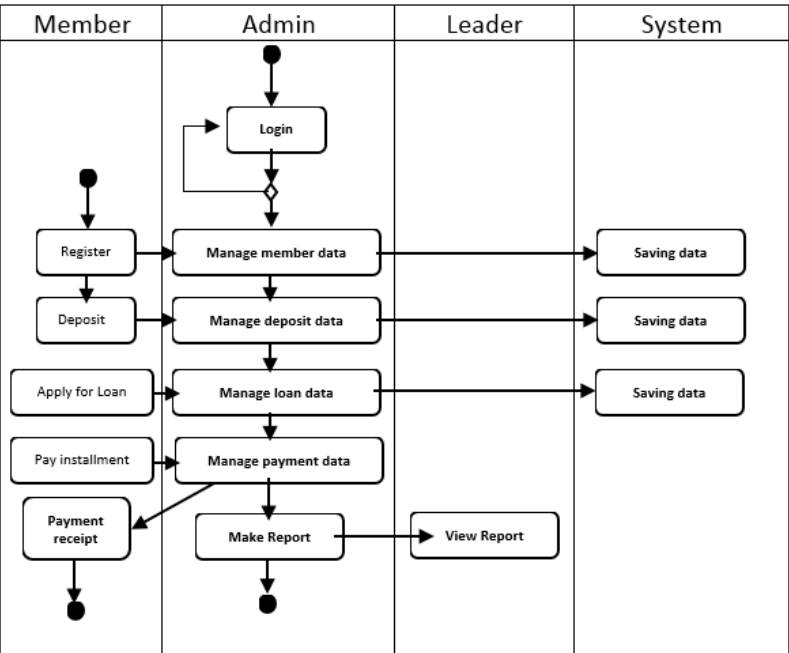

Fig 4. Activity Diagram of Cooperative Information Systems

3. Activity Diagram Design

Activity diagram is a diagram describing procedural logic, business process, and work flow [8]. Seen in Fig 4 is the activity diagram of cooperative information systems, and the flow conducted by each actor.

\section{F. Construction and Testing}

Further stage was constructing and testing the established information systems. It was carried out by using the desktopbased Java programming language, and continued by integrating it with the DBMS MySQL-based database through the developed interface. The results can be seen in Fig 5, 6, and 7 .

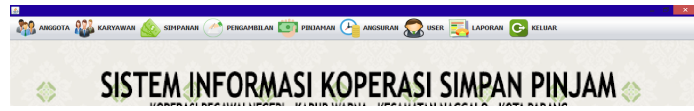

Fig 5. The Display of Main Page on Cooperative Information Systems

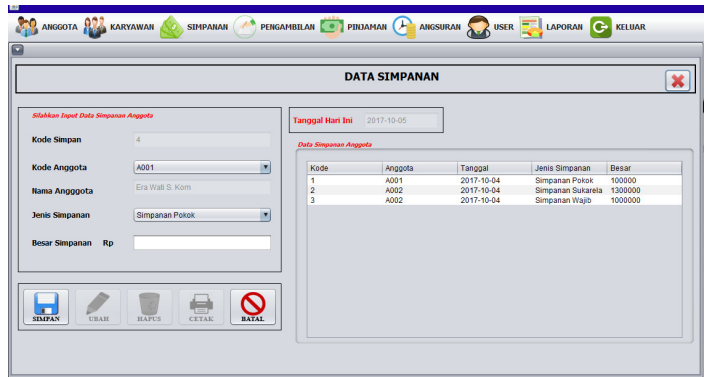

Fig 6. The Display of Saving Page

Seen in Fig 5 is the main page of cooperative information systems. This page presents the member menu, employee, saving, withdraw, loan, installment, user, report, and sign out. In addition, at the point where the member would hand in their monthly carrying charges, and replacement reserve, it would be input into the saving menu as presented in Figure 6 . Whereby, when the member would like to take the loan, it would be input into the loan menu as presented in Fig 7. 


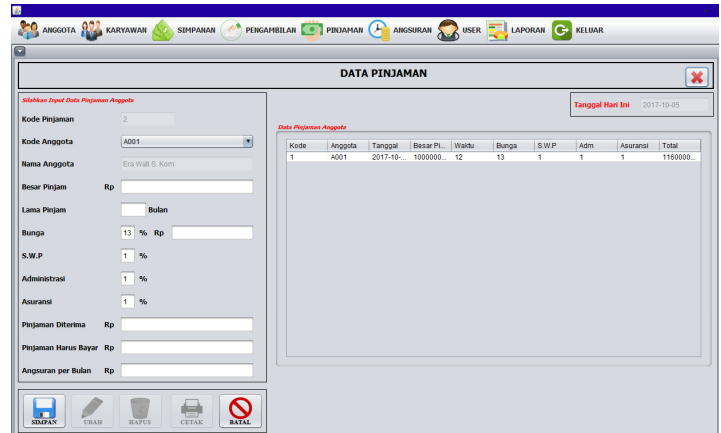

Fig 7. The Display of Loan Page

\section{G. Implementation}

Having been through the testing process, the implementation of information systems onto the Perumdak housing complex was taken. It was accompanied by providing the training for the committee and the employee who were incharge with this systems.

\section{CONCLUSSION}

The development of cooperative information systems can be carried out using the FAST method. This method has several stages starting from the preliminary investigation, problems analysis, needs analysis, decision analysis, designing and testing, and to the implementation. This systems development method is object-oriented in the form of UML, which are Use Case Diagram, Activity Diagram, Class Diagram, and Sequence Diagram. The systems development takes desktop-based JAVA Programming language, and DBMS MySQL software. This systems has also been implemented onto Perumdak Housing Complek Cooperative as the object of this recent research.

\section{REFERENCES}

[1] "Undang-Undang Republik Indonesia Nomor 25 Tahun 1992 Tentang Perkoperasian.".

[2] H. Arifianto, "Peran Koperasi Simpan Pinjam dan Efektifitas Kredit dalam Meningkatkan Kesejahteraan Anggota." Fakultas Ekonomi dan Bisnis Universitas Brawijaya, Malang, 2015.

[3] M. Azmi, "Perancangan Dan Implementasi Sistem Informasi Koperasi Pegawai Negeri (KPN) Pada Koperasi 'Kapur Warna' Kecamatan Naggalo Kota Padang," Matics, vol. 3, p. 6, 2014.

[4] V. E. Meri Azmi, Yance Sonatha, Ronal Hadi, Humaira, "Rancang Bagun Sistem Informasi Simpan Pinjam Pada Koperasi Jasa Keuangan Syariah." Saintek, Lembaga Penelitian Universitas Negeri Padang, Padang, pp. 172-179, 2015.

[5] N. Hasyim, N. A. Hidayah, and S. W. Latisuro, "RANCANG BANGUN SISTEM INFORMASI KOPERASI BERBASIS WEB PADA KOPERASI WARGA BARU MTS N 17 JAKARTA," vol. 7, no. 2, pp. 1-10, 2014.

[6] "Laporan Akhir Tahun pada Rapat Akhir Tahun 2017 Koperasi Komplek Perumdak." 2017.

[7] A.-B. bin Ladjamudin, "Analisis dan Desain Sistem Informasi," Graha Ilmu, 2005.

[8] M. Fowler, UML Distilled, 3rd ed. ANDI Yogyakarta, 2005.

[9] J. L. Metode, L. D. Bentley, and K. C. Dittman, "Metode desain dan analisis sistem," p. 21, 2006.

[10] Rudianto, Akuntansi Koperasi, 2nd ed., no. 25. Jakarta: Erlangga, 2010.

[11] A. Hendryani, "Rancang Bangun Sistem Informasi Remunerasi Jasa Pelayanan RSUD Kepahiang Bengkulu Menggunakan Metode FAST," vol. 01, pp. 9-16, 2017

[12] Medina-Quintero, J.M et al, Enterprise Technology in Support for Accounting Information System. An Innovation and Productivity Approach. Journal of Information System and Technology Management vol 12, No.1, pp 29-44. 2015 